\title{
Raymond Carver and the Ethos of Drinking
}

\author{
David McCracken \\ Coker College, Hartsville, USA \\ Email: dmccracken@coker.edu
}

Received February $18^{\text {th }}$, 2013; revised March $19^{\text {th }}$, 2013; accepted April $13^{\text {th }}, 2013$

\begin{abstract}
Copyright (c) 2013 David McCracken. This is an open access article distributed under the Creative Commons Attribution License, which permits unrestricted use, distribution, and reproduction in any medium, provided the original work is properly cited.
\end{abstract}

In Raymond Carver's "Careful”, “Gazebo”, and "Chef's House”, characters depend on the process of drinking as a paradigm to understand their lives. In these three stories, the characters rely upon alcohol as a solution to problems paradoxically caused by their addiction to alcohol.

Keywords: Raymond Carver; Alcoholism

Many of Raymond Carver's characters understand intuitively they are dependent upon alcohol, and they apply instinctively the dynamics of their addiction (what they can internalize) to the instability in their relationships (what they cannot internalize). To these characters, there is an ethos attached to drinking that they think helps them to understand more clearly their chaotic lives. In several of Carver's stories, this drinking ethos provides characters some semblance of clarity.

In "Careful", Lloyd is faced with a difficult decision, sobriety and marriage or drinking and divorce. Initially, Lloyd isolates himself in an attic apartment to get sober, not for himself but for his wife. Although he has agreed to try to stop drinking, he has not really "listened" to her comments or her body language, both clearly suggesting she has had enough of his behavior. In the first sentence, the narrator states, "After a lot of talking — what his wife, Inez, called assessment—Lloyd moved out of the house and into his own place" (Carver, 1989: p. 264). Lloyd's lifestyle has changed since the separation, and he is having difficulty adjusting to his new alcoholic reality. An example of this is when Lloyd wonders about his breakfast menu:

One morning he woke up and promptly fell to eating crumb doughnuts and drinking champagne. There'd been a time, some years back, when he would have laughed at having a breakfast like this. Now, there didn't seem to be anything very unusual about it. [...] Time was when he would have considered this a mildly crazy thing to do, something to tell friends about. Then, the more he thought about it, the more he could see it didn't matter much one way or the other. He'd had doughnuts and champagne for breakfast. So what? (Carver, 1989: p. 265)

Inez's attempt to unclog Lloyd's ear suggests she might want to reconcile, but after she finds Lloyd's champagne stashed in the bathroom and realizes Lloyd has chosen booze over her, she is fed up with the situation. His decision simply to ignore Inez and their relationship in favor of drinking is apparent at the end of the story: "He took the bottle of champagne into the living room and made himself comfortable on the sofa. [...] He wasn't in the habit of drinking from the bottle, but it didn't seem that much out of the ordinary" (Carver, 1989: p. 277). Lloyd under- stands the process of drinking much more clearly than the responsibilities attached to his marriage, and after his ear is cleaned, he returns to the comfort of alcohol over his wife.

In "Gazebo", the characters' relationship is dependent upon their drinking. Duane sets the tone of the story: "That morning [Holly] pours Teacher's over my belly and licks it off. That afternoon she tries to jump out the window. [...] I go, 'Holly, this can't continue. This has to stop'” (Carver, 1981: p. 21). As he begins to assess his relationship, Duane comments upon the significance of alcohol in his and Holly's lives: "Drinking's funny. When I look back on it, all of our important decisions have been figured out when we were drinking. Even when we talked about having to cut back on our drinking, we'd be sitting at the kitchen table or out at the picnic table with a six-pack or whiskey. When we made up our minds to move down here and take this job as [motel] managers, we sat up a couple of nights drinking while we weighed the pros and the cons" (Carver, 1981: p. 25). The current crisis is the result of an affair Duane has had with Juanita, one of the motel maids, and this has provided justification for the couple's heavy drinking. Throughout the story, Duane constantly keeps his and Holly's glasses full of liquor. He states, "I stopped cleaning the pool. It filled up with green gick so that the guests wouldn't use it anymore. I didn't fix any more faucets or lay any more tile or do any of the touchup painting. Well, the truth is we were both hitting it pretty hard. Booze takes a lot of time and effort if you're going to do a good job with it” (Carver, 1981: p. 26). Duane finally decides the couple has "reached the end of something" (Carver, 1989: p. 27), and Holly fantasizes about the two of them starting over. She asks Duane if he remembers an occasion when they stopped by an elderly couple's home and asked for a drink of water. She describes the couple as “dignified” (Carver, 1981: p. 28) and admits she has hope they will eventually be like the elderly couple. Ironically, Holly describes the remembrance in the context of drinking.

In "Chef's House", Edna hopes that her estranged husband is recovering from alcoholism. The first sentence of the story suggests her skepticism that this will occur: "That summer Wes rented a furnished house north of Eureka from a recovered alcoholic named Chef. [...] He said he was on the wagon. I knew 


\section{MCCRACKEN}

about that wagon. [...] I listened to him talk. He didn't slur his words" (Carver, 1989: p. 297). Reunited with her husband, Edna describes their experiences in terms of drinking: "We drank coffee, pop, and all kinds of fruit juice that summer. The whole summer, that's what we had to drink. I found myself wishing the summer wouldn't end. I knew better, but after a month of being with Wes in Chef's house, I put my wedding ring back on. I hadn't worn the ring in two years. Not since the night Wes was drunk and threw his ring into a peach orchard" (Carver, 1989: p. 298). As the story progresses, Edna reveals that this reunion is based upon falsehoods. Edna writes affectionate letters to her children but has little emotion for them; she mentions the children "kept their distance" (Carver, 1989: p. 298). Even though Wes goes to what he calls "Don't Drink meetings" (Carver, 1989: p. 298), she can tell he is ready to relapse. When Chef evicts Wes from the house, Wes immediately places this news into a drinking context. He remembers the new tenant, Chef's daughter Linda, as Fat Linda, one of his previous drinking buddies. Edna fears that Wes's reaction signifies that he will begin drinking: "Wes had that look about him. I knew that look. [...]” (Carver, 1989: p. 300). In a desperate attempt to deflate the situation, Edna asks Wes to pretend that the eviction, as well as most of the problems in their lives, never happened. Edna bases her final decision on how well she can assess Wes's sobriety.

Drinking is undoubtedly a form of escapism, but in Carver's stories, it actually enables several characters to redirect their focus toward reality. Granted, once they see reality, they often immerse themselves back into alcoholic fantasy. Regardless, in Carver's fictional universe, drinking gives many characters a sense of stability through which they can evaluate their lives, even if this stability is fleeting.

\section{REFERENCES}

Carver, R. (1981). Gazebo. In What we talk about when we talk about love (pp. 21-29). New York: Vintage.

Carver, R. (1989). Careful. In Where I'm calling from (pp. 264-277). New York: Vintage.

Carver, R. (1989). Chef's house. In Where I'm calling from (pp. 297302). New York: Vintage. 